\title{
INTERRUPÇÃO VOLUNTÁRIA DA CARREIRA EM PROL DA MATERNIDADE
}

\author{
VOLUNTEER INTERRUPTION OF CAREER IN FAVOUR OF MATERNITY
}

Recebido em 17.08.2017. Aprovado em 14.11.2017

Avaliado pelo sistema double blind review

DOI: http://dx.doi.org/10.12712/rpca.v11i5.1056

\author{
Harrison Bachion Ceribeli \\ Universidade Federal de Ouro Preto (UFOP), Ouro Preto/MG, BRASIL \\ harrisonbceribeli@hotmail.com
}

\section{Edlane Regis da Silva}

Universidade Federal de Ouro Preto (UFOP), Ouro Preto/MG, BRASIL

edlane.silva@yahoo.com.br

\section{Resumo}

Ao mesmo tempo em que as mulheres passaram a ter mais abertura no mercado de trabalho, muitas também se depararam com dificuldades diversas para se manterem nele depois de assumirem o papel de mães. Neste contexto, definiu-se como objetivo de pesquisa analisar a motivação das mulheres que decidiram abdicar da carreira para se dedicarem integralmente à maternidade, assim como a percepção delas a respeito da experiência que vivenciaram a partir dessa decisão e suas perspectivas futuras. Realizou-se uma pesquisa exploratória de cunho qualitativo. A coleta de dados efetuou-se por meio de entrevistas em profundidade com 14 mães que abdicaram da carreira. Os dados foram analisados por meio da análise de conteúdo. Os resultados evidenciaram que as políticas empresariais e governamentais que são voltadas para as profissionais que possuem filhos ainda são insuficientes para lhes garantirem condições adequadas para permanecerem no mercado sem terem que escolher entre a carreira e a maternidade.

Palavras-chave: Maternidade. Diversidade de gênero nas organizações. Mulheres nas organizações.

\begin{abstract}
Contemporary society is shaped by innumerable political, economic and social contradictions, which also encompass gender issues. At the same time as the labor market became more open to women, many of them also had various difficulties to stay in it after assuming the role of mothers. In this context, the objective of this research was to analyze the motivation of women who decided to give up their career to dedicate themselves fully to motherhood, as well as their perception of the experience lived after that decision and their future perspectives. An exploratory qualitative research was carried out. Data were collected through in-depth interviews with 14 mothers who had abdicated their careers. Data were analyzed through content analysis. The results showed that business and government policies that target the professionals with children are still insufficient to guarantee them adequate conditions to remain in the labor market without having to choose between career and motherhood.
\end{abstract}

Keywords: Maternity. Gender diversity in organizations. Women in organizations. 


\section{Introdução}

A crescente participação feminina no mercado de trabalho tem sido, ao longo dos últimos anos, temática de muitas pesquisas no campo das Ciências Sociais Aplicadas, promovendo discussões pertinentes à pós-modernidade, que perpassam desde as análises de estatísticas sobre a diversidade de gênero na força de trabalho das organizações até a questão das desigualdades entre os gêneros e a relação desse fenômeno com os novos formatos familiares que se desenham na sociedade atual (MAGALHÃES, 2010).

Por outro lado, há ainda uma matéria pouco explorada no meio acadêmico, que se relaciona com o aumento da pressão que o universo do trabalho exerce sobre os indivíduos de modo geral, obrigando-os a dedicarem cada vez mais tempo de suas vidas às atividades laborais, o que afeta, com mais severidade, as mulheres, que normalmente são também responsáveis pela maior parte ou pela totalidade das tarefas domésticas.

Com isso, a mulher pós-moderna passou a conviver com novos desafios em seu planejamento de vida, sendo impelida a navegar entre a dúvida de ser mãe e se dedicar a essa função de maneira integral, abrindo mão da carreira, mesmo que de forma temporária, ou conciliar a maternidade e a carreira, ou até mesmo não ser mãe em hipótese alguma, priorizando a realização profissional (SIMÕES; HASHIMOTO, 2012).

Dado que muitas mulheres, frente a esse dilema, decidem ou estão sujeitas, por questões situacionais, a interromperem suas carreiras, esse fenômeno merece ser objeto de mais ampla investigação na área da Ciência Administrativa, à medida que pode estar atrelado a fatores organizacionais.

Neste contexto, definiu-se como objetivo para esta pesquisa analisar a motivação das mulheres que decidiram abdicar da carreira para se dedicarem integralmente à maternidade, assim como a percepção delas a respeito da experiência que vivenciaram a partir dessa decisão e suas perspectivas futuras.

A justificativa para o presente estudo reside, primeiramente, no fato de que o tema abordado foi, até o momento, pouco explorado na academia, apesar de ser de extrema importância e atualidade para a sociedade. Além disso, não se deve desprezar que, no campo de investigação da Administração, questões de gênero têm-se mostrado uma linha promissora de pesquisa, dada a desigualdade histórica no tratamento dispensado a homens e mulheres nas organizações. Por fim, tem-se que se considerar que os resultados obtidos podem favorecer a reflexão em torno da insuficiência das práticas organizacionais e políticas públicas voltadas para as profissionais que possuem filhos.

\section{Referencial teórico}

\section{A mulher, o mercado de trabalho e a maternidade}

$\mathrm{Na}$ última década houve um aumento no número de mulheres no mercado de trabalho. Dados do censo do Instituto Brasileiro de Geografia e Estatística (IBGE) de 2012 apontam que a participação do gênero feminino no mercado de trabalho, que, em 2003, era de $43 \%$, aumentou, em 2011, para 45,4\%.

Entre os fatores que contribuíram para o avanço da participação feminina no mercado de trabalho, citase o desenvolvimento de métodos contraceptivos, que permitiram às mulheres decidir quando engravidar e quantos filhos ter; obviamente, outros fatores também se fizeram importantes, tais como as inovações tecnológicas e a globalização do mercado, que facilitaram a especialização das mulheres em diversas áreas, fazendo com que elas passassem a ter acesso a profissões mais técnicas (BAYLÃO; SCHETTTINO, 2014).

Há, todavia, uma visível distinção de gênero no mercado de trabalho. As mulheres, não raras vezes, são designadas a trabalharem em áreas que exigem baixa qualificação profissional e, por conseguinte, com remuneração inferior. E, mesmo existindo muitas empresas que prezam pela diversidade de gênero em seu quadro de funcionários, de certa forma, as mesmas não estão isentas da discriminação em suas políticas de gestão de pessoas (CAPELLE; MELO; SOUZA, 2013).

Soma-se a isso o fato de que, conforme destacam Leone e Baltar (2008), a participação do gênero feminino no universo laboral resultou, em muitos casos, nas duplas jornadas de trabalho, à medida que muitas mulheres continuam sendo responsáveis, de forma exclusiva, pelos afazeres domésticos e criação dos filhos.

Percebe-se, desta forma, que, mesmo que a mulher tenha conquistado mais espaço em diferentes dimensões de sua vida, permanece o discurso social dominante que associa a identidade feminina à maternidade, sendo papel dela cuidar e educar os 
filhos, abdicando, se necessário, de sua carreira e dos cuidados consigo mesma (PATIAS; BUAES, 2012).

E, como a mulher assume sozinha o papel de liderança operacional no lar, muitas vezes acaba abrindo mão de cuidados estéticos e se descuidando da própria saúde, à medida que as poucas horas que lhe restam, especialmente na parte da noite, são empregadas unicamente para dar atenção às tarefas escolares dos filhos, limpar e organizar o ambiente doméstico, além de gerenciar eventuais conflitos na própria família (VIEIRA; AMARAL, 2013).

Ou seja, a mulher pós-moderna tende a enfrentar uma sobrecarga descomunal de tarefas na busca de conciliar sua carreira e atribuições domésticas, tendo cada vez menos tempo para si mesma, menos saúde e tudo isso sem o devido apoio de seu companheiro (SINA, 2005).

Ademais, como se essa sobrecarga não bastasse, muitas mulheres que optaram por conciliar carreira e maternidade experimentam ainda o sentimento de culpa em relação a sua ausência nas atividades que envolvem cuidados com o filho e o lar (VIEIRA; AMARAL 2013). Não raro, a mulher tem a crença de que ela, como mãe, é a única capaz de cuidar de seu bebê, trazendo para si sentimentos de ansiedade e insatisfação, já que a decisão de não interromper, mesmo que temporariamente, sua carreira faz com que ela tenha que lidar com o fato de passar menos tempo com a criança, bem como de terceirizar os cuidados maternos (BELTRAME; DONELLI, 2012).

Além disso, nos casos em que a mulher busca conciliar a construção e consolidação de sua carreira e a maternidade, tem-se uma série de conflitos, devido à pressão social que ela enfrenta para postergar o retorno ao trabalho depois do nascimento do filho e à pressão organizacional para regressar ao trabalho e retomar a carreira rapidamente (BELTRAME; DONELLI, 2012).

Soma-se aos fatores supramencionados o fato de que, perante a sociedade, o status familiar (casamento, número de filhos, entre outros) tem impacto positivo na carreira masculina, enquanto na feminina esse impacto é negativo, à medida que, para os homens, carreira e família são vistas como complementares, enquanto que, para as mulheres, ser mãe e se dedicar à carreira profissional são dois papeis ainda encarados pelos empregadores como conflituosos e até mutuamente excludentes (TANURE; CARVALHO
NETO; ANDRADE, 2006). Segundo McIntosh et al. (2012), a ascensão profissional das mulheres enfrenta obstáculos mais severos de acordo com o número de filhos que elas têm e por terem filhos dependentes em idade escolar.

Por tudo isso, muitas mulheres estão optando por postergarem ou até evitarem a maternidade para não terem suas carreiras afetadas e não terem que lidar com conflitos provenientes da tentativa de conciliação. Todavia, de acordo com Barbosa e Coutinho (2007), o adiamento da maternidade, esperando a consolidação da carreira no mercado de trabalho, às vezes se estende ao ponto de que a pretensão de ser mãe se torna inviável, seja por ser uma gravidez de risco, ou pela condição apropriada nunca chegar.

Finalizando, não é possível ignorar que existe uma visão amplamente disseminada pela mídia, seja por meio de novelas, filmes ou ainda publicações impressas, que coloca a mulher em constante conflito entre ser mãe e ser livre, à medida que as personagens femininas que se dedicam integralmente à maternidade muitas vezes são apresentadas como pessoas não realizadas de forma plena (TOMAZ, 2015). Adicionalmente, a presença da executiva no mundo corporativo trouxe a imagem mítica da mulher poderosa, que tem ausência de sentimentos, que não se apega aos relacionamentos facilmente e que não tem, entre suas prioridades, o desejo de ser mãe (TANURE; CARVALHO NETO; ANDRADE, 2010). Essa representação da mulher pós-moderna acaba estimulando e respaldando a decisão de postergar a maternidade.

\section{Os dilemas da mulher envolvendo a maternidade}

O dilema entre a maternidade e a carreira, que leva muitas mulheres a postergarem a primeira, pode ser fonte de grande ansiedade (BARBOSA; COUTINHO, 2007; LIMA, 2012). E, como consequência desse dilema, a taxa de nascimento do primeiro filho da mulher aumentou $81 \%$ na idade entre 35 e 39 anos nos Estados Unidos, fato que revela a mudança do comportamento feminino, sua crescente participação no mercado de trabalho e a prioridade que tem sido dada à formação e consolidação/ascensão profissional (RIBEIRO et al., 2007).

Segundo Beltrame e Donelli (2012), a busca por estabilidade e independência financeira pode ser apontada como alguns dos principais fatores que levam ao adiamento da maternidade. Nesta mesma linha, Lima (2012) argumenta que muitas mulheres 
postergam a maternidade esperando o "tempo certo", aguardando a obtenção de estabilidade financeira e consolidação da relação junto ao companheiro.

Todavia, conforme alertam Beltrame e Donelli (2012), a decisão de postergar não significa uma opção pela não maternidade, o que gera angústia no futuro, pois muitas mulheres tornam-se menos férteis quando alcançam seus objetivos profissionais e/ou pessoais.

Assim, o desconhecimento e as idealizações geram uma ilusão que não equivale, muitas vezes, à realidade, pois o adiamento da maternidade pode fazer com que a mulher tenha que lidar com angústias e sofrimentos provenientes das preocupações com fertilidade, complicações na gravidez, falta de energia, obrigações financeiras, complicações genéticas, entre outras (LIMA, 2012).

Por sua vez, tem-se também o dilema, após a gravidez, entre se ausentar do mercado e vivenciar integralmente a experiência da maternidade ou conciliar a carreira e o papel de mãe; tal impasse, assim como o anterior, tem causado muita angústia e ansiedade nas mulheres (OLIVEIRA et al., 2011).

Contra a decisão de interromper a carreira em decorrência do nascimento de um filho pesa o impacto negativo desta determinação sobre a empregabilidade futura da mulher, sendo esse efeito associado ao tempo de duração da interrupção (BÄCHMANN; GATERMANN, 2017). Ademais, o abandono temporário do mercado de trabalho formal por motivos familiares pode afetar negativamente a ascensão profissional da mulher depois que ela retorna (EVERTSSON; GRUNOW; AISENBREY, 2016; McINTOSH et al., 2012), assim como a remuneração que receberá (CEBRIÁN; MORENO, 2015; THEUNISSEN et al., 2011).

Por outro lado, Edwards (2006) assinala uma séria de fatores que acabam motivando a saída da mulher do mercado de trabalho: a ocorrência de conflitos constantes entre as demandas familiares e as profissionais; as manifestações de estresse e sintomatologia ansiosa; o desenvolvimento de crenças negativas acerca do próprio desempenho como mãe; e o desequilíbrio na divisão de tarefas relativas aos cuidados domésticos e dos filhos.

A duração do afastamento do mercado de trabalho muitas vezes está associada ao nível salarial da mulher, à medida que as profissionais que auferem rendimentos mais elevados tendem a optar por interrupções mais curtas na carreira por razões familiares (BÄCHMANN; GATERMANN, 2017). Logo, torna-se importante que políticas públicas sejam implantadas, visando tornar mais acessíveis e menos onerosos os serviços de cuidados infantis, assim como ocorreu na Noruega, favorecendo o retorno mais rápido das mulheres, com rendimentos menores e que tiveram filhos, ao mercado de trabalho (RØNSEN; KITTERØD, 2015).

Entretanto, mesmo com a possibilidade de terceirizar parte de suas atividades, muitas profissionais assimilam, de uma sociedade patriarcal e machista, como sendo exclusivamente suas as funções socialmente atribuídas ao gênero feminino, o que inclui as responsabilidades domésticas, como a limpeza e organização da casa, e os cuidados com os filhos, levando à sobrecarga e, por conseguinte, à exaustão feminina, que acaba por contribuir para que a mulher se afaste do mercado de trabalho (AMARAL, 2013).

Entre as mulheres que optam por interromper a carreira para se dedicarem à maternidade, muitas pretendem retornar ao mercado de trabalho no futuro, porém, em profissões alternativas, com o intuito de evitarem seus antigos empregos pouco flexíveis e contornarem a discriminação etária e a desatualização profissional (LOVEJOY; STONE, 2012).

Frente a essa realidade, não é possível ignorar que o mercado de trabalho penaliza a maternidade ao invés de facilitar o reingresso da mulher que se decidiu pela interrupção da carreira com o intuito de proporcionar cuidados integrais a seus filhos nas primeiras fases de suas vidas (ARUN; ARUN; BOROOAH, 2004).

Importante destacar que, apesarde todas as desvantagens do ponto de vista profissional, as mulheres que se dedicam a serem mães em tempo integral experimentam grande satisfação pessoal devido ao elevado significado e relevância que atribuem ao trabalho materno (JUNG; HEPPNER, 2015).

Para finalizar a presente reflexão, deve-se acrescentar que o impacto da maternidade no trabalho e do trabalho na maternidade, que podem levar ao abandono do mercado laboral e interrupção da carreira, é um assunto complexo, à medida que envolve diversos fatores, tais como o contexto pessoal e social da mulher, a idade dos filhos e seu grau de dependência dos cuidados maternos, o tempo de afastamento necessário do mercado de trabalho, as expectativas e satisfação pessoal com o papel de mãe, os valores 
sociais da mulher e de sua família e a satisfação pessoal ligada à profissão e carreira (OLIVEIRA et al., 2011).

\section{A flexibilização do trabalho e a maternidade}

Caso decida pela conciliação, ao retornar ao mercado de trabalho, a mulher que viveu a experiência da maternidade se vê obrigada a optar por uma forma de terceirização das atribuições maternas, o que pode se dar de várias maneiras, podendo ser destacadas quatro: creches e pré-escolas; creche familiar (pequenos grupos de crianças na casa do cuidador); cuidado na casa da criança por uma babá ou parente; ou ainda cuidado na casa da própria babá ou parente. Destacase que essa separação mãe-bebê não acontece somente nos casos de mães que trabalham; há mães que fazem essa opção devido à sobrecarga das tarefas do lar e busca de um tempo para si mesmas (RAPOPORT; PICCININI, 2004).

Todavia, ocorre que, muitas vezes, a mulher que se afastou temporariamente do mercado de trabalho para se dedicar à maternidade, ao retomar sua carreira, não consegue se desvincular do papel de mãe hiperzelosa, o que gera conflitos psicológicos e sobrecarga, que trazem como consequência imediata o desgaste físico e mental e, ao longo do tempo, doenças e transtornos diversos (CASTRO, 2006).

Pensando nisto e nos muitos papeis desempenhados pelas pessoas nas famílias, no trabalho e na sociedade em geral, as organizações passaram a implantar propostas que melhoram a saúde dos trabalhadores e a qualidade de suas relações sociais, permitindo que eles equacionem melhor as demandas profissionais e aquelas provenientes das demais esferas de sua vida (GOULART JÚNIOR et al., 2013).

Neste contexto, práticas como home-office, telework, flexibilização e até mesmo redução da jornada de trabalho estão se tornando cada vez mais comuns no meio empresarial (CERIBELI; FERREIRA, 2016), sendo que, dentre tais práticas, Pacelli, Pasqua e Villosio (2013) destacam a redução da jornada, argumentando que a possibilidade de estar vinculada a um emprego de meio período tende a reduzir a probabilidade de a mulher deixar o mercado de trabalho depois da maternidade.

Segundo Goulart Júnior et al. (2013), atualmente, há um grupo crescente de "empresas familiarmente responsáveis", cujas políticas de gestão ancoram-se na flexibilização, respeito e compromisso mútuo. Ainda segundo os mesmos autores, essas empresas podem ser identificadas por quatro grupos de políticas de gestão de pessoas: (1) flexibilização do tempo e espaço; (2) benefícios sociais; (3) apoio ao trabalhador; e (4) serviços familiares.

O primeiro grupo de políticas possibilita jornada de trabalho flexível ou que o trabalho seja feito em casa, sendo essas opções abertas a todos os funcionários e independente de qualquer fator, somente nos casos de emergência familiar, filhos pequenos, doentes ou incapacitados. O segundo grupo inclui os planos de saúde, seguros de vida, entre outros benefícios que melhoram a qualidade de vida dos funcionários e seus familiares. Já o terceiro refere-se a aconselhamento legal, financeiro, psicológico e de carreira para os profissionais da empresa. Por fim, o quarto inclui, entre outras ações, a criação de creche na própria organização, garantindo tranquilidade aos pais e a possibilidade de estarem próximos aos filhos mesmo durante o tempo que estiverem trabalhando (GOULART JÚNIOR et al., 2013).

Importante ressaltar, todavia, que, mesmo com a adoção dessas políticas e práticas que, em tese, favorecem os múltiplos papeis assumidos na sociedade atual, as mulheres que optam por conciliar a maternidade e a carreira ainda precisam lidar com dois embates distintos: um no ambiente familiar, resultante do distanciamento dos filhos que muitas vezes acaba acontecendo, e outro no ambiente laboral, este resultante da necessidade de terem que lidar com colegas, chefes e subordinados desconfiados, preconceituosos e até mesmo resistentes em relação a sua ascensão profissional (BRUSCHINI; PUPPIN, 2004).

\section{Aspectos metodológicos}

Considerando que se pretendeu contribuir com a compreensão das motivações, conflitos e entraves que experimentam as mulheres que abdicaram voluntariamente, em algum momento de sua vida, da carreira para se dedicarem integralmente ao exercício da maternidade, optou-se por uma pesquisa exploratória de cunho qualitativo.

A pesquisa exploratória se fez necessária à medida que se buscou maior aproximação e entendimento de uma temática ainda pouco explorada na academia, sendo este tipo de investigação recomendado para clarificar o tema estudado e abordá-lo com maior profundidade (RAUPP; BEUREN, 2003). 
Por sua vez, a pesquisa qualitativa, de acordo com Monteiro (2016), permite um maior comprometimento com causas sociais, aumentando a interação entre elas e a teoria, além de permitir maior compreensão das percepções e respostas dos indivíduos às situações vivenciadas. Ademais, a abordagem qualitativa de pesquisa favorece o conhecimento da natureza e características do fato social (RAUPP; BEUREN, 2003).

Para coleta de dados, o método adotado neste estudo foi a entrevista em profundidade, que auxilia o pesquisador a se conectar com a realidade dos atores sociais investigados e descobrir aspectos essenciais e subjetivos que a caracterizam (QUIVY; CAMPENHOUDT, 1998). Nesse tipo de entrevista, o pesquisador tem a possibilidade de interagir com os indivíduos de forma direta e aprofundada, coletando informações acerca de experiências, motivações, crenças, valores e outros elementos que tenham moldado ou que exerçam influência sobre sua visão de mundo e comportamentos (BONI; QUARESMA, 2005).

A entrevista em profundidade caracteriza-se pela interação direta com os sujeitos (MONTEIRO, 2016) e, por isso, torna-se possível, empregando este método, elucidar detalhes da realidade investigada e descrever as situações utilizando as próprias palavras dos atores sociais (CASSIANI et al., 1996).

Foram conduzidas entrevistas com 14 mulheres que abdicaram da carreira para se dedicarem, integralmente, ao exercício da maternidade. Para compor a amostra da pesquisa, adotou-se a técnica de amostragem por conveniência, utilizando-se o grupo de pessoas disponíveis e voluntárias às quais os pesquisadores têm acesso (CARMO; FERREIRA, 2008).

A seleção das entrevistadas limitou-se às habitantes do Estado de Minas Gerais, especificamente das cidades de Mariana e Ouro Preto, respeitando os seguintes critérios: (1) deveriam ter optado voluntariamente pela saída do mercado de trabalho; e (2) esta decisão deveria ter sido motivada pela maternidade.

Das 14 entrevistadas, sete possuíam ensino superior completo ou equivalente e sete não. Esta escolha metodológica justifica-se ao se pressupor que a escolaridade das participantes da pesquisa impacta sua visão de mundo e influencia sua percepção em relação ao dilema entre carreira e maternidade. Após estudarem cerca de quatro a seis anos para obterem uma formação melhor, as mulheres que concluíram o ensino superior tendem a vislumbrar maior crescimento profissional e almejar sua independência financeira. Tal linha de raciocínio baseia-se no pressuposto de que, com a educação superior, as mulheres buscam mudanças sociais e culturais, passando a ocupar também mais espaço e usufruir de maior estima no mercado de trabalho.

Neste sentido, não é incoerente partir do pressuposto de que mulheres com maior escolaridade, ao optarem por se dedicarem exclusivamente à maternidade em detrimento de suas carreiras, teriam que abrir mão de salários mais altos, de cargos com maior status e da profissão escolhida, diferindo suas percepções acerca dessa decisão daquelas nutridas por mulheres com menor nível de instrução, o que justifica o estudo dos dois grupos e confrontação das respostas obtidas junto a cada um deles.

A análise dos dados coletados foi realizada utilizandose a técnica denominada análise de conteúdo, que permite fazer uma descrição objetiva e sistemática a partir da interpretação do conteúdo das comunicações analisadas e das mensagens passadas pelos entrevistados (CARMO; FERREIRA, 2008), sendo uma importante ferramenta para condução de estudos socioantropológicos (FONSECA JUNIOR; WILSON, 2005).

\section{Apresentação dos resultados das entrevistas}

Para facilitar a apresentação dos resultados, foram atribuídas numerações a cada uma das entrevistadas, de 1 a 14. Como se observa no Quadro 01, as entrevistadas 1 a 7 possuíam menor grau de escolaridade, enquanto as entrevistadas 8 a 14 possuíam, no mínimo, graduação ou equivalente (magistério). No quadro 01, também está descrito o último cargo ocupado pelas entrevistadas antes da decisão de interromper a carreira e a idade que elas possuíam quando foram mães e atualmente.

RPCA | Rio de Janeiro | v. 11 | n. 5 | out./dez. 2017 | 116-139 | 121 
Quadro 1. Perfil das entrevistadas

\begin{tabular}{|c|c|c|c|c|}
\hline Entrevistada & Grau de Escolaridade & $\begin{array}{c}\text { Idade } \\
\text { atual }\end{array}$ & $\begin{array}{c}\text { Idade em que } \\
\text { foram mães }\end{array}$ & Último Cargo \\
\hline $\mathbf{1}$ & $2^{\circ}$ grau incompleto & 27 & 25 & Vendedora \\
\hline $\mathbf{2}$ & $2^{\circ}$ grau completo & 52 & 26 & Secretária \\
\hline $\mathbf{3}$ & $2^{\circ}$ grau completo & 33 & 33 & Telefonista \\
\hline $\mathbf{2}$ & $2^{\circ}$ grau completo & 32 & 26 & Secretária \\
\hline $\mathbf{5}$ & $2^{\circ}$ grau incompleto & 25 & 23 & Empregada Doméstica \\
\hline $\mathbf{6}$ & Superior Incompleto & 23 & 22 & Faturista \\
\hline $\mathbf{7}$ & $2^{\circ}$ grau completo & 30 & 30 & Auxiliar administrativo \\
\hline $\mathbf{8}$ & Magistério & 53 & 26 & $\begin{array}{c}\text { Professora de escola } \\
\text { pública }\end{array}$ \\
\hline $\mathbf{9}$ & Formação tecnológica em Design de Moda & 36 & 33 & Gerente de boutique \\
\hline $\mathbf{1 0}$ & $\begin{array}{c}\text { Graduação em Letras e Mestrado em } \\
\text { Educação Tecnológica em andamento }\end{array}$ & 37 & 23 & $\begin{array}{c}\text { Professora em escola } \\
\text { pública }\end{array}$ \\
\hline $\mathbf{1 1}$ & $\begin{array}{c}\text { Magistério, pós-graduação em Arte } \\
\text { e Cultura Barroca, curso técnico em } \\
\text { Restauração de Obras de Arte }\end{array}$ & 40 & 19 & $\begin{array}{c}\text { Professora de Arte e } \\
\text { tutora de Pedagogia }\end{array}$ \\
\hline $\mathbf{1 2}$ & Graduação em Geologia & 34 & 24 & Bolsista de Mestrado \\
\hline $\mathbf{1 3}$ & Graduação em Nutrição & 48 & 34 & $\begin{array}{c}\text { Professora de Ensino } \\
\text { Superior }\end{array}$ \\
\hline 14 & Graduação em Farmácia & 42 & 27 & $\begin{array}{c}\text { Coordenadora de } \\
\text { controle de qualidade }\end{array}$ \\
\hline
\end{tabular}

Fonte: Elaborado pelos autores (2017).

\section{Grupo I: mulheres sem formação superior que abdicaram da carreira}

As profissionais que participaram da pesquisa primeiramente foram questionadas a respeito do planejamento da maternidade. Quatro delas não planejaram; as três que fizeram o planejamento apontaram como fatores motivacionais a vontade de ser mãe, a segurança atribuída ao tempo de casamento, a idade, o fato de gostarem de crianças e até mesmo a inexistência de qualquer impedimento.

Quatro das mulheres entrevistadas afirmaram também que não sofreram nenhum tipo de pressão depois da decisão de se tornarem mães; as outras três passaram por diversas situações em que isto ocorreu e tiveram que lidar com comentários sobre o quanto se gasta com um filho e as dificuldades de cuidar de uma criança.

Muitas pessoas falam para gente: você vai ser mãe? Nossa! Acabou o sossego! A partir do dia que falou que tá grávida, não tem sossego mais não, viu. (ENTREVISTADA 2).

As pessoas falavam: nossa, você vai ter filho? Você tá grávida? Você vai ver que desespero que é cuidar de filho. Filho gasta muito dinheiro. Leite é caro. Fralda é cara. Você vai passar muita dificuldade! (ENTREVISTADA 7)

Quando questionadas a respeito de em qual momento se deu a decisão (e não o ato) de abandonar a carreira, quatro entrevistadas apontaram que tal decisão foi tomada depois do nascimento do filho e três delas, durante a gravidez. Em seguida, questionou-se o que motivou a decisão de abdicar da carreira, sendo que as respostas apontaram para o fato de não ter alguém para cuidar da criança caso permanecessem trabalhando (um familiar, por exemplo). Outros fatores destacados foram o desejo de se dedicarem à educação e criação do filho; a 
insegurança em deixar a criança sob os cuidados de uma pessoa desconhecida ou que não iria ser cuidadosa como a mãe; fatores de saúde que dificultariam cuidar do lar e dos filhos e também trabalhar fora de casa; e a questão financeira, já que o salário recebido seria integralmente gasto para pagar alguém para cuidar dos filhos, ou até não seria suficiente para arcar com os custos de manter uma babá, creche ou pré-escola.

Foram questões financeiras e a insegurança que eu acho que bate em toda mãe, né? Tipo: ou colocar o filho em uma creche, ou ter que deixar com alguma babá. Você ter uma pessoa mesmo de confiança, então, assim, acho que foram estes fatores principais. (ENTREVISTADA 3)

Dificuldade mesmo, do tempo em que fica longe, a questão do salário que a gente recebe não suprir a necessidade de pagar uma escola, babá. (ENTREVISTADA 7)

Duas profissionais que participaram da pesquisa chamaram a atenção para o fato de que percebiam, nas organizações onde trabalhavam, distinções entre o tratamento dado a homens e mulheres, tais como a maior cobrança por ser mãe e menos oportunidades de crescimento, o que também incentivou a decisão de deixarem o emprego.

Com certeza sempre teve. Eu percebi muito também a partir do momento que eu fui mãe, as cobranças ficaram maiores, eles queriam que eu fizesse horários muito maiores sabendo que eu tinha filho, era muito mais complicado. Eu sentia muito grande essa diferença. Com certeza pesou na minha decisão, porque se eu tinha que ficar entre meus filhos e o trabalho, e eu não podia cumprir o horário que era o horário correto, eu preferia ficar com meus filhos e não ter todo esse estresse. (ENTREVISTADA 2)
Com o intuito de compreender melhor como as organizações lidam com a maternidade, questionaramse as entrevistadas acerca da existência, onde trabalhavam, de políticas voltadas para as funcionárias que possuíam filhos. Somente uma das mulheres respondeu positivamente a tal questionamento, fazendo referência à flexibilização para o aleitamento materno e em casos de consultas médicas (ambas previstas em lei). Tal dado evidencia o quanto muitas empresas precisam avançar para garantir condições favoráveis à permanência das mulheres no mercado de trabalho depois do nascimento dos filhos.

Posteriormente, quando indagadas acerca de preconceitos sofrido por outras mães nas organizações em que trabalhavam, apenas uma dentre as sete entrevistadas afirmou nunca ter presenciado algo assim; as demais afirmaram que tal situação era recorrente e contribuiu para sua decisão de abandonar a carreira.

Todas tiveram muitos problemas em relação à necessidade de cuidar do filho. Se um dia precisavam levar ao médico, então elas eram crucificadas, elas tinham que dar conta de tudo. E era sempre um estresse se precisasse sair mais cedo, ou fazer alguma coisa em relação aos filhos ou à casa. E com isso eu estava cada vez mais certa da minha decisão de sair. (ENTREVISTADA 2)

Todas as mães que participaram da pesquisa também afirmaram que, quando abdicaram efetivamente da carreira profissional, possuíam uma dupla jornada de trabalho e se sentiam sobrecarregadas, o que lhes incentivou a se dedicarem integralmente à maternidade.

Eu fazia tudo em casa, dar conta de tudo, das crianças, de casa, comida, marido, e mais o serviço fora. $\mathrm{O}$ meu trabalho era um trabalho que, na época, a gente estava com muitas mudanças de planos: Plano Collor, Plano Sarney... Então eu trabalhava tinha dia 12/13 horas, eu tinha minha mãe que sempre foi minha companheira, que morava perto de mim, então ela sempre 
estava tentando de uma forma ou de outra me ajudar, lavar uma roupa, passar, pegar as crianças na escola. Quando meu marido chegava do trabalho, ficavam com ele. Tive, sim, algumas ajudas. Mas eu já estava ficando esgotada. Eu não sabia a quem atendia: ao meu trabalho, meu marido, meus filhos. Estava ficando complicado... As ajudas que eu tive foram ótimas, mas a mãe sempre faz a maior parte. (ENTREVISTADA 2)

De forma complementar, as mulheres entrevistadas relataram que deixaram de se cuidar em diversos momentos, principalmente quando tinham que trabalhar fora de casa, encarregar-se dos afazeres domésticos e ainda cuidar do filho, devido à sobrecarga de responsabilidades.

Ao serem questionadas a respeito do posicionamento do companheiro no que se refere à decisão de abdicar da carreira, seis dentre as sete entrevistadas afirmaram ter recebido apoio e/ou estímulo. Apenas uma das mulheres relatou que o companheiro não concordou inicialmente com tal decisão.

Ele é que ficou falando na minha cabeça para cuidar dos nossos filhos. Com certeza me afetou, porque, por mim, eu continuava trabalhando, mas aî não tinha ninguém para cuidar dos filhos, e meu marido ficava falando na minha cabeça, acabou que eu deixei mesmo o trabalho. (ENTREVISTADA 4)

Ele não foi muito a favor, não. Ele não queria que eu me dedicasse totalmente à maternidade, não. Ele sempre foi a favor mesmo de eu trabalhar fora e tentar conciliar isso. Isso não afetou minha decisão, porque, por mim, eu não iria mais trabalhar fora. (ENTREVISTADA 3)
A maior parte das mães informou durante as entrevistas que, além dos companheiros, os familiares apoiaram suas decisões e que isto, de certa forma, incentivouas para que realmente abdicassem da carreira em prol da maternidade. Somente duas entrevistadas não receberam apoio familiar, o que causou um pouco de desconforto quanto à decisão tomada.

Teve gente que achou horrível. Eu estava abrindo mão de um emprego que eu era concursada como secretária. Tem gente que fala até hoje que eu devia ter estudado mais, que eu devia ter investido na minha carreira profissional [...]. Então eu fui muito corajosa de abrir mão de tudo e eu ouvi de tudo e ouço até hoje. (ENTREVISTADA 2)

As entrevistadas também foram indagadas acerca da possível cobrança ou apoio das pessoas com quem conviviam quanto à decisão que tomaram de se dedicarem integralmente à maternidade. Nas respostas obtidas, ficou evidenciada a cobrança e as críticas por parte de grande parte dos indivíduos que pertencem aos círculos sociais dessas mulheres.

A gente ouve isso em qualquer lugar. As pessoas acham assim: só porque você é mãe e trabalha dentro de casa, você é uma à toa. Então, sempre tem esses comentários por trás, tipo "você é uma à toa e só fica dentro de casa". Isso não me afeta, a gente fica meio chateada, mas o importante é eu estar com meu filho. (ENTREVISTADA 1)

Muita gente fala: filho cresce, você é boba, você vai ter seu dinheiro. Mas o problema é que eu não tinha com quem deixar os meus filhos, o dinheiro que eu teria que pagar para alguém não compensava, aí por isso que decidi. (ENTREVISTADA 4)

Até mesmo o preconceito das pessoas, de falar: a mulher tem que trabalhar. Independentemente de estar com filho ou não, as pessoas meio que não entendem. (ENTREVISTADA 3) 
Seis das profissionais mencionaram que atualmente sofrem pressão para reingressarem no mercado de trabalho e se sentem aflitas por isso, pensando a respeito de com quem iriam deixar os filhos, o que iriam fazer e como iriam se reinserir no mercado de trabalho.

As pessoas falam, né, que eu não deveria ter largado o emprego para ser mãe. Olha, eu fico às vezes muito chateada com a pessoa, que ela não conhece mesmo as nossas condições e ficam falando assim. É ruim. (ENTREVISTADA 1)

Sempre quando a gente está em família ou grupo de amigos, todo mundo acha que eu tenho que retornar, tenho que estudar, tenho que procurar emprego, tenho que fazer concursos e tal. Todo mundo dá palpite, todo mundo acha que isso ou aquilo é melhor para gente, sendo que nem a gente mesmo sabe o que é bom para a gente. Tem dia que isso me afeta, tem dia que eu nem ligo. Deixa para lá e pronto, mas tem dia que afeta. (ENTREVISTADA 2)

Sim, sempre tem essa pressão. É mais tipo assim, eu fico pensando, a gente cria um laço maternal muito grande, então é mais o meu psicológico, que fica, tipo assim: ai meu Deus... de deixar com alguém, até mesmo com a minha mãe, que eu sei que vai cuidar muito bem dele, mais é meu psicológico mesmo, de ficar com a cabeça aqui, e de ter que trabalhar e a cabeça ficar em casa. (ENTREVISTADA 3)

Três dentre as sete mulheres relataram que, depois de abdicarem da carreira para cuidarem do filho, recebiam ajuda do companheiro nos afazeres domésticos e que a divisão das tarefas era justa; outras três disseram que tinham algum apoio nos cuidados do filho e da casa, mas que a divisão dessas tarefas não era justa; por fim, uma das entrevistadas afirmou que não possuía apoio, pois o companheiro e ela moravam em cidades diferentes.
Com certeza a divisão não é justa, porque é difícil você encontrar um homem que te ajude no serviço da casa, ainda mais agora, que eu não estou trabalhando. E eu também penso que é eu mesmo que tenho que fazer. Ele não lava nem o prato que ele usa. (ENTREVISTADA 4)

Durante as entrevistas, as mães também foram questionadas se, depois da experiência que vivenciaram, tomariam uma decisão diferente atualmente. Em resposta, cinco afirmaram que a decisão seria a mesma, enquanto duas disseram que fariam diferente, devido ao preconceito que enfrentaram e à dificuldade de reingressar novamente no mercado.

Faria, porque eu acho que o amor e o tempo que eu tive com meus filhos... Eu tenho recordações lindas, de estar com eles, de ter curtido cada coisa, de ter ensinado a cada coisinha para eles. Eu só acho que, se eu fosse mais nova, já teria voltado a fazer outras coisas. Não acho que precisava ficar tanto tempo, mas hoje, se eu fosse mãe novamente, novamente eu pararia. (ENTREVISTADA 2)

Não, porque, apesar de ter falado em colocar na ponta do lápis, tem outra questão. Além do dinheiro, é de se sentir útil na sociedade, de produzir. A questão maior é que, quando você está fora do mercado de trabalho, a pressão psicológica é maior do que quando você está lá dentro, sem tempo para cuidar de seu filho, ou seja, se você cuida do seu filho e não trabalha você é um encostado, mas o preconceito é menor se seu filho está numa creche, sendo paga ou não. (ENTREVISTADA 7)

De forma complementar, indagou-se se as profissionais acreditavam que a maternidade dificultaria suas carreiras, caso não houvessem deixado o mercado de trabalho. Uma delas respondeu negativamente, outra 
respondeu que, na época em que tomou a decisão de interromper a carreira, acreditava que sim, mas atualmente acredita que não; duas afirmaram que isso dependeria da empresa, citando o machismo existente em várias organizações; e as outras três concordaram que a maternidade dificultaria suas carreiras.

$\mathrm{Eu}$ acho que sim. Porque a gente serve para as pessoas quando a gente está lá, depois que a gente sai a gente não tem valor nenhum. Quando minha chefa ficou sabendo que eu estava grávida, então ela falou: "Eu acho melhor..." - eu nem tinha sofrido os sangramentos ainda - simplesmente ela falou: "Acho que vou ter que dar um jeito de te mandar embora, porque você está grávida". (ENTREVISTADA 5)

Quatro mães também acreditavam que a carreira, por sua vez, atrapalharia a maternidade, caso não tivessem deixado o mercado de trabalho, justificando essa crença com base no tempo curto da licença maternidade e na necessidade da presença maternal para acompanhar o crescimento do filho.

Adicionalmente, abordou-se nas entrevistas se as mães já cogitaram voltar ao mercado de trabalho e contratar alguém ou pedir a familiares para cuidar de seus filhos no horário de trabalho e o porquê de não terem levado essa ideia adiante. Nas respostas obtidas, verificouse que todas pensam ou já pensaram em fazer isso, esbarrando em diferentes fatores, como a dificuldade de encontrar alguém confiável para cuidar da criança, a dificuldade de conseguir uma vaga em uma creche pública e o baixo salário que seria recebido, insuficiente para arcar com custos de uma babá ou creche.

Naépocaemqueeutrabalhava, eutive até uma experiência com isso, mas não deu certo. Contratei uma pessoa que ficou e eu tentei trabalhar, mas várias coisas não valiam a pena. Primeiro, o salário era um salário pequeno com relação ao que eu tinha que pagar para uma pessoa ficar dentro da minha casa, então não valia a pena. Qual o sentido de eu pagar a mesma coisa que eu ganho lá fora? E eu achei que não foi uma boa experiência, os meninos reclamavam, as coisas não eram da forma como eu gostava, então não foi uma boa ideia. (ENTREVISTADA 2)

Em seguida, quando as entrevistadas foram questionadas acerca da possibilidade de voltarem ao mercado de trabalho futuramente, as respostas convergiram para um possível retorno ao trabalho quando os filhos estivessem maiores. Apenas a Entrevistada 2, que possui 52 anos, não pensa em retornar ao mercado justamente por causa da idade.

Todavia, as seis profissionais que pretendem voltar ao mercado futuramente acreditam que enfrentarão dificuldades, devido a fatores como a experiência que deixaram de acumular por terem interrompido a carreira, o tempo longo de afastamento e a resistência dos empregadores para reinserção das mães, consequência dos preconceitos arraigados no meio empresarial, ancorados no machismo historicamente consolidado nas relações de trabalho.

Futuramente, sim. Mas creio que eu vou ter muita dificuldade [...] tenho muitas amigas que abdicaram disso e até hoje, por exemplo, tem quatro anos que não conseguiram voltar para o mercado de trabalho. (ENTREVISTADA 3)

Esse futuro podia até ser hoje. Eu sofri preconceito descarado, numa empresa aqui de Ouro Preto que eu fui fazer uma entrevista, e ele me perguntou por que eu tinha aquela lacuna no meu currículo, eu peguei e falei, porque eu fui mãe, eu escolhi ser mãe, agora eu estou tentando voltar ao mercado. [...] E no final da entrevista ele falou para mim assim: "A mulher, quando volta da maternidade, não está preparada para o mercado de trabalho. Tenta ver se você consegue estudar mais, até mesmo algum trabalho autônomo, porque quando a mulher volta, ela não consegue ser a mesma pessoa". (ENTREVISTA 7) 
Para finalizar a entrevista com esse grupo de mães, indagaram-se quais são os benefícios, tanto do ponto de vista pessoal quanto no que se refere à criação do filho, atribuídos à dedicação integral à maternidade e também as desvantagens de tal decisão.

Como benefícios, as entrevistadas citaram os maiores cuidados dedicados na criação e educação dos filhos, assim como a possibilidade de acompanhar de forma mais próxima todo o desenvolvimento da criança e auxiliá-la em tudo que precisasse. Em relação às desvantagens, duas delas não pontuaram nenhuma; as demais levantaram a questão financeira e o conflito psicológico devido à sensação de não ser útil na sociedade.

Eu acho que a parte boa é você poder acompanhar o crescimento do seu filho, acompanhar tudo, desde quando ele é bebezinho, porque essa parte não volta mais, o primeiro passo, as primeiras palavras. Agora, a parte negativa por eu não estar trabalhando... O dinheiro às vezes fica bem apertado, fica bem apertado nas contas poder comprar alguma coisa pra ele, mas foi mais benefícios que coisas negativas. (ENTREVISTADA 1)

O benefício é que a gente consegue acompanhar de perto todos os momentos da criança, quando ele começa a falar, quando começa a andar... Amamentação prolongada que não tem preço. Ele tem um ano e quatro meses e ainda mama no peito. Eu nunca tive com ele doença, somente uma gripe. Graças a Deus não teve mais doença nenhuma. Essas são as vantagens. O ponto negativo disso tudo aí é você não ter uma condição financeira que teria se estivesse trabalhando e até mesmo a parte psicológica, de se sentir útil dentro da sociedade (ENTREVISTADA 7).

\section{Grupo II: mulheres com formação superior que abdicaram da carreira}

No grupo das mulheres com formação superior que abdicaram da carreira, as entrevistadas foram também questionadas sobre o planejamento da maternidade. Cinco delas não planejaram; as outras duas afirmaram que sim e que foram motivadas pelo desejo de ter uma família grande e de se tornarem mãe, assim como pelo relacionamento que possuíam com seu companheiro. Entre essas mulheres, não houve nenhum relato de qualquer tipo de pressão proveniente da decisão de se tornarem mães.

Em seguida, quando questionadas a respeito de em qual momento se deu a decisão de abandonar a carreira, seis entrevistadas apontaram que tal decisão foi tomada depois do nascimento do filho, pois não estavam conseguindo conciliar carreira e maternidade, além de se sentirem pressionadas, pois queriam dar maior atenção aos filhos e, ao mesmo tempo, não queriam que eles fossem cuidados por terceiros; uma ainda levantou a questão financeira, pois possuía mais de um filho. Somente uma das mães relatou que, já durante a gravidez, começou a pesquisar a respeito de creche e babá e concluiu que as despesas que teria não eram viáveis.

Eu não estava conseguindo coordenar a maternidade com o trabalho mesmo. Eu estava tendo muita cobrança, trabalhava demais, e chegava em casa e não conseguia dar a atenção que as meninas precisavam, e aí chegou num ponto em que não teve jeito mesmo, eu tive que escolher entre uma coisa ou outra. (ENTREVISTADA 14)

Toda vez que algum filho adoecia a minha mãe dizia: "Esse menino está adoecendo, porque está na creche". Assim! Ela falava de forma explícita! Eu acho que isso afetava o meu psicológico. Igual eu estou te falando, a gente já nasce com a culpa quando filho nasce... Eu era muito infeliz nessa época por causa disso. (ENTREVISTADA 10)

Quando eu tive a primeira filha, eu não podia abdicar da minha 
carreira profissional, porque a minha renda fazia parte do orçamento familiar. Embora eu tivesse vontade, eu não tinha possibilidade. Isso não ocorreu na minha primeira gravidez. $\mathrm{Na}$ minha segunda gravidez, depois que eu ganhei o neném, aí sim eu decidi abdicar da minha profissão, porque o que eu ganhava realmente não dava para bancar creche para os dois. Não justificava. (ENTREVISTADA 10)

As mães também foram questionadas acerca da existência de distinção no tratamento dado a homens e mulheres onde trabalhavam antes. Duas não percebiam tais distinções. As demais relataram diferenças de caráter salarial, nas oportunidades de ascensão profissional e relacionadas a cargos e tarefas, além do receio por parte da chefia em relação à maternidade e do preconceito arraigado na cultura da organização. $\mathrm{E}$, apesar de nenhuma ter associado essa diferenciação à decisão de interromper a carreira, várias destacaram que o preconceito sofrido recorrentemente contribuiu para seu afastamento do mercado de trabalho.

Eu trabalhei lá cinco anos. Nunca tive promoção, aumento de salário... [...] A maioria dos supervisores era homem. [...] $\mathrm{Na}$ época, o número de mulheres que ocupavam cargos mais elevados era minoria. (ENTREVISTADA 10)

$\mathrm{Na}$ verdade, lá, a gente sabia que o homem no mesmo cargo que você ganhava mais. [...] E se você não estava bem com alguma coisa do trabalho, você era questionada. As pessoas às vezes falavam: "Ah, tá de TPM". Você está chateada com alguma coisa, mas nunca era o trabalho, sempre era o fato de ser mulher. (ENTREVISTADA 14)

Assim como foi feito no primeiro bloco de entrevistas, com o intuito de compreender melhor como as empresas lidam com a maternidade, questionaram-se as mães acerca da existência, onde trabalhavam, de políticas voltadas paras as funcionárias que possuíam filhos, sendo que somente duas responderam positivamente a tal indagação, fazendo referência à flexibilização do horário. Novamente, ficou evidente que as organizações ainda possuem muitos pontos a serem aperfeiçoados para permitirem a permanência das mulheres, em condições favoráveis, no mercado de trabalho após a maternidade.

Não tinha creche, auxílio, flexibilização da carga horária, muito menos do local de trabalho. Você tinha que trabalhar até mais tarde por qualquer tipo de entrega de trabalho, e eles não olhavam nada disso em especial. Pra gente, não tinha diferenças, não era nem diferença, eles não levavam a maternidade sequer em consideração. (ENTREVISTADA 10)

Em seguida, todas as profissionais afirmaram que, quando abdicaram da carreira profissional efetivamente, possuíam uma dupla jornada de trabalho e se sentiam muito sobrecarregadas, apesar de receberem algum auxílio nas tarefas domésticas, o que lhes incentivou a se dedicarem integralmente à maternidade.

Meu esposo me ajudava, não posso me queixar, mas é lógico que eu sentia a sobrecarga, porque a casa é da mulher, não tem jeito. Mesmo que a mulher tenha uma empregada doméstica, igual no meu caso. Mas quem gerencia a empregada sou eu, quem gerencia a casa sou eu, quem gerencia as atividades dos filhos... Isso é tudo papel da mulher. Então, existe sobrecarga, dupla jornada, tripla jornada, quádrupla jornada e por aí vai. (ENTREVISTADA 10)

Minha mãe me ajudava. Mas, quando minha mãe não podia ficar, a minha filha mais velha pegava a van na porta de casa, ia para a escola, eu deixava a mais nova em uma creche, da creche eu 
ia para o meu trabalho, depois das $11 \mathrm{~h} 30 \mathrm{eu}$ voltava para minha casa, esperava a van da filha mais velha, dava almoço, levava de novo para a escola, aí depois a van pegava a mais nova na creche, e à tarde eu tinha que estar em casa às $18 \mathrm{~h}$, porque a van da mais nova estava lá. Isso daí foi uma das coisas que mais pesou, porque eu não dava conta de tudo. (ENTREVISTADA 14)

Complementarmente, todas as entrevistadas relataram que abdicaram, em diversos momentos, de cuidados consigo mesmas, principalmente quando estavam trabalhando e cuidavam da casa e dos filhos. Frente à sobrecarga de tarefas e responsabilidades, elas priorizam os filhos.

Não consigo. É bem mais difícil... Você esquece um pouco de você. A minha filha mais velha me cobra que eu tô saindo toda descabelada... [...] Não dá para fazer tudo bem feito, não dá para cuidar sempre de mim e não dá para ter uma casa super arrumada. E eu ainda abdico de várias coisas... [...] Como você tem que abdicar de várias coisas quando trabalha também. É a mesma coisa na maternidade, só que é mais puxado, você não tem como ficar doente. No trabalho, você pega um atestado e fica em casa, até você ficar bem. Quando você é mãe, você não pode pegar atestado, vai ter que se virar. (ENTREVISTADA 12)

Quando questionadas acerca do posicionamento do companheiro na decisão de abdicarem da carreira, cinco dentre as sete entrevistadas afirmaram ter recebido apoio e estímulo dos companheiros. Uma delas afirmou que o companheiro não concordou inicialmente, enquanto a outra havia se separado do marido. me incentivou mais ainda a ficar em casa. Isso me afetou com certeza, foi uma decisão tomada em conjunto. Mas ele foi totalmente respeitoso. Ser pai e ser mãe é se doar totalmente a um novo ser, e ele se dedicou ao ponto de falar assim: "Pode deixar por minha conta financeira e responsabilidade, porque eu dou conta do recado. $\mathrm{E}$ você fica por conta da casa e do filho". (ENTREVISTADA 9)

A princípio, ele não queria. Achava que eu sou muito inteligente para abrir mão de um bom emprego para ficar em casa... O que pesou mesmo foi a dupla jornada. Só eu sabia o tanto que eu trabalhava. (ENTREVISTADA 8)

Além dos companheiros, a maioria das entrevistadas afirmou que os familiares apoiaram suas decisões, e que isso foi de grande valia para que abdicassem da carreira em prol da maternidade. Apenas duas das entrevistadas não receberam o apoio dos familiares.

Eles ficaram super decepcionados. Assim: se formou, você ficou cinco anos estudando e agora não vai fazer nada? Vai ficar em casa igual sua avó ficou a vida toda? Mas isso não me afetava, não. (ENTREVISTADA 12, 2017)

Por outro lado, todas as profissionais mencionaram que sofreram e sofrem pressão em seu círculo social pela decisão de abdicarem da carreira, e que a sociedade em geral cobra que conciliem o papel de mãe com a profissão, o que as deixa aflitas e se sentindo constantemente pressionadas.

Foram muito poucas as pessoas que falavam assim: "Olha, você se dedicou tanto a sua carreira de designer de moda, e agora você vai ser dona do lar e mãe?" Mas sempre tem uns enxeridos... Isso não me afetou psicologicamente, mas esses comentários chegam 
a ser inconvenientes. (ENTREVISTADA 9)

Sim, por parte de todo mundo que sabe que você tem um curso superior e que você não está exercendo sua profissão. Então, assim, todo mundo tem uma tendência de ver as pessoas só como trabalhadores e acha que todo mundo precisa estar no mercado de trabalho o tempo todo, full time. E aí, assim, então, só que você tem um filho e o que você faz com ele? Aí você terceiriza? Então manda ele para escola com três meses? Chama uma pessoa? Chama uma vizinha? Entrega para sua mãe? Faz qualquer coisa, mas você precisa estar no mercado de trabalho. Então existe uma urgência em que todos têm que estar, em que todos têm que fazer da mesma forma e mesmo que você não precise, então você fala: "Olha, eu não preciso de trabalhar, porque o que meu marido ganha é mais do que suficiente para a gente", mas isso não justifica. Então não é só questão financeira, você pode ter mais dinheiro, não é só por isso, é porque você tem que estar inserido naquilo ali. [...] Eu sofri muito com isso de não ter minha mãe ali, que minha mãe não fazia um lanche para mim, imagina se eu sofri com três anos, imagine uma criança de seis meses? (ENTREVISTADA 12)

Muita, muita gente falando que era uma fase que eu estava passando, que eu tinha que ser firme, que eu estava trabalhando e que eu ia me arrepender. (ENTREVISTADA 13)

Quando eu resolvi mesmo sair, muitas amigas, principalmente, falavam: "Não, você não pode", "Você tem 17 anos de formada", "Já é uma profissional superpreparada no mercado e tudo", "Você não pode fazer isso", "Você está jogando sua carreira fora". Não me afetou, porque eu já tinha tomado a minha decisão. É fácil falar, difícil é as pessoas entenderem e passar pelo que você está passando. É bem mais complicado. (ENTREVISTADA 14)

Seis das profissionais também mencionaram que sofrem pressão para reingressarem no mercado de trabalho e que acreditam que, principalmente por terem estudado, essa cobrança é maior. Além disso, relataram que, muitas vezes, acabam internalizando essa pressão e se cobrando pelo retorno.

De uma maneira geral, quando você começa a conversar com as pessoas, elas falam: "Nossa, que bom, você deve mesmo estudar", "você ainda é nova", "tem que voltar mesmo para o mercado de trabalho". E tem também uma cobrança da gente mesmo com a gente mesmo. (ENTREVISTADA 10)

Nossa,já passou tanto tempo que eu
acho que todo mundo acostumou
tanto assim comigo. Acho que
ninguém me vê mais no mercado
de trabalho... [...] Me veem muito
mais como mãe. Mas que tem
uma decepção, tem. Minha família
é super decepcionada com isso,
e agora eu fiz outro curso, e aí
eles falam: "E aí, o que você vai
fazer com mais de um diploma?"
(ENTREVISTADA 12)

Quatro dentre as sete entrevistadas relataram que recebem ajuda do companheiro nos afazeres domésticos, mesmo que estão fora do mercado de trabalho, apesar de não considerarem a divisão de tarefas justa. Uma das entrevistadas é separada e por isso não recebe tal apoio do companheiro, enquanto duas mencionaram que dividem de forma bastante equitativa as tarefas domésticas com o companheiro.

Importante citar que, durante as entrevistas, foram recorrentes as frases que indicavam certo conformismo com a divisão pouco equilibrada das 
tarefas domésticas, o que demonstra que as próprias entrevistadas acabam internalizando o machismo com que convivem.

Apoio eu tenho com o cuidado, mas, que é justo e que é de igual para igual, jamais... Nunca foi e nunca vai ser... Na casa de ninguém... Não acredito. [...] Você é a mãe, ele é o pai, mesmo que você não esteja trabalhando, a responsabilidade da casa e dos filhos deveria ser sempre dividida... [...] Mas nunca o trabalho doméstico é dividido em partes iguais. $\mathrm{O}$ homem está sempre em vantagem e vai estar em todas as famílias, não só na minha. E devo incluir a minha nisso por mais que meu esposo faça uma ou outra coisa. É sempre desigual. (ENTREVISTADA 10)

Tenho ajuda, mas a divisão não é justa. Não sei se poderia ser diferente, porque acho que é uma questão muito de homem ou mulher. A mulher é muito mais ligada na questão da criança e da casa, de longe percebe que tem alguma coisa, que precisa fazer alguma coisa. O pai tem que ser uma coisa muito certeira, tipo, eu quero comer agora, ele vai e arruma e a mãe já mais ou menos prediz aquilo ali. Ela pensa: "já tem muito tempo que meu filho almoçou, então daqui a pouco ele vai estar com fome, vou arrumar alguma coisa". Então eu acho que é questão da mulher mesmo, acaba se colocando mais ativa. (ENTREVISTADA 12)

Durante as entrevistas, as mães também foram questionadas se, depois da experiência que vivenciaram, tomariam a mesma decisão atualmente. Seis das entrevistas, em resposta, afirmaram que a decisão seria a mesma devido ao fato de terem superado as dificuldades enfrentadas, ao amor incondicional, à possibilidade de terem participado de todo processo educacional do filho e estarem sempre presentes.
Apenas uma disse que faria diferente por acreditar que seria possível ter conciliado.

Sim, porque os filhos... Eles são um amor incondicional, é tudo muito lindo, a gravidez, ter filhos, só quem tem sabe o que é. É trabalhoso, mas o retorno... Receber um beijo de manhã, tem coisas que não tem preço. (ENTREVISTADA 11)

Depois de ter a experiência que tenho, acho que não. Igual eu estou te falando, filho nenhum morre, eu não deixaria. Não deixaria, porque eu acho que dá para conciliar. A mulher é muito guerreira mesmo, dá para conciliar, dá para seguir, mesmo com todas as dificuldades. (ENTREVISTADA 10)

Também se indagou se as profissionais acreditavam que a maternidade dificultaria suas carreiras, caso não houvessem deixado o mercado de trabalho. Somente uma respondeu negativamente. As demais acreditam que a maternidade dificultaria suas carreiras devido à dupla jornada que teriam que enfrentar e a necessidade de priorizar uma ou outra, tendo, por exemplo, que recusar uma promoção caso fosse necessário viajar muito ou mudar de cidade. Complementarmente, todas as entrevistadas acreditam que a carreira, por sua vez, atrapalharia a maternidade caso não tivessem deixado o mercado de trabalho, devido, principalmente, às viagens de trabalho e jornadas laborais extensas, que dificultariam o convívio com os filhos.

As mães também foram questionadas se já cogitaram voltar ao mercado de trabalho e contratar alguém para cuidar de seus filhos no horário de trabalho e o porquê de não terem levado essa ideia adiante até o presente momento. Em resposta, todas afirmaram que pensam ou já pensaram em regressar. Contudo, vários fatores as fizeram desistir, tais como a dificuldade de encontrar alguém de confiança para cuidar da criança, o custo com babá ou creche e o sentimento de que ainda não era o momento de retomar a carreira.

Em seguida, perguntou-se se havia possibilidade de voltarem futuramente ao mercado. Em respostas, seis relataram que pensam em regressar quando os 
filhos já estiverem maiores. Apenas a Entrevistada 8, que já possui 53 anos de idade, afirmou não ter essa pretensão.

Entretanto, as seis profissionais que pretendem, futuramente, voltar ao mercado de trabalho não pensam em retornar na mesma área, pois acreditam que terão dificuldades devido à falta de experiência e existência de profissionais melhor qualificadas, pois não interromperam a carreira. Por causa disso, algumas estão retomando os estudos, seja na mesma área ou não, assim como pensando em abrir o próprio negócio.

Eu estou me preparando para voltar já para o mercado. Meus filhos estão com 11 e 15 anos... [...] Eu parei de trabalhar, agora, para voltar ao mercado de trabalho, eu estou estudando mais. Para conseguir voltar, não é simplesmente parar e voltar do mesmo ponto onde você parou. (ENTREVISTADA 10)

Sim. Talvez em outra área. Acho que, para eu retornar, eu vou ter que me reciclar, ter que me atualizar. Mas eu penso em não trabalhar em empresa... Trabalhar informalmente mesmo, com bolos, por exemplo... De forma autônoma, eu mesma fazer meu tempo. (ENTREVISTADA 13)

Durante as entrevistas, todas as mães relataram o quanto o dilema entre a carreira e a maternidade lhes angustiava e como é complexa a decisão de priorizar esta última. $\mathrm{O}$ medo, o abalo psicológico, a insegurança e o sentimento de inferioridade foram aspectos recorrentes nas falas das entrevistadas. Algumas mencionaram que buscaram apoio psicológico para lidar com tal angústia.

Eu sabia o que eu estava fazendo, eu tinha que tomar uma decisão. Claro que fiquei abalada, até emocionalmente, porque eu fiz magistério sonhando em ser professora e eu tentei. Quando eu era solteira, eu lecionava. Depois casei e, a partir desse momento, vim morar em outra cidade. Eu não tinha minha família para ajudar, então tive que abandonar mesmo a carreira. Como eu gosto muito de ler, então eu fiquei com o mundo só com os livros mesmo, porque não dava para conciliar em casa. Fica um aprendizado meio limitado, porque a gente só aprende... No caso do professor, ele aprende e quer ensinar, e eu ficava só aprendendo. (ENTREVISTADA 8)

Quando eu decidi, foi uma coisa muito instantânea, quer dizer, a princípio eu fui parando aos poucos. [...] Aí chegou uma hora em que eu falei: "Chega, basta." Como eles estavam pequenos, meu tempo era muito corrido, então eu nem parei para pensar sobre ter parado de trabalhar. À medida que o tempo foi passando que eu comecei a sentir, tipo, você começa a abrir mão de um monte de coisa que você gostava de fazer... Tem a questão financeira... Por um lado é bom que você passa a economizar, para de gastar com um monte de bobagem, mas tem um peso, principalmente psicológico. Teve uma fase em minha vida que eu tive que procurar apoio, porque eu não estava sabendo lidar, estava me sentindo inferiorizada pelo fato de não estar trabalhando. (ENTREVISTADA 13)

Você fica meio perdida, sem saber. Porque é muita cobrança, é cobrança do profissional e cobrança dentro de casa, das suas filhas que você tem que estar mais presente, a escola te cobrando que você tem que estar presente e eu do outro lado, tinha o lado profissional... O mercado de trabalho te cobrando... As pessoas querem sempre mais, por mais que você dê, é insuficiente, e essa cobrança que eu tinha que dar mais, eu não estava dando conta 
nem de dar mais para empresa e nem para minhas filhas. Eu cheguei a um ponto em que eu falei: "Não dá." (ENTREVISTADA 14)

Para encerrar as entrevistas, as mulheres foram questionadas a respeito dos benefícios, do ponto de vista pessoal e para a criação do filho, atribuídos à dedicação integral à maternidade, e as desvantagens de tal decisão. Como benefícios, foram citados o fato de estarem mais próximas dos filhos e de não terem que lidar com preocupações por deixá-los com terceiros, a maior participação na educação, a maior segurança e um acompanhamento mais cuidadoso. Como desvantagens, foram citadas a carreira estagnada, a questão financeira e a dependência que acaba sendo gerada em torno da mãe. Algumas entrevistadas, todavia, não mencionaram nenhuma desvantagem.

Eu acho que acaba que passa uma segurança para a criança, você consegue potencializar várias coisas, você nota as dificuldades que ela tem e consegue trabalhar com aquilo ali. Por exemplo: tá demorando muito a falar, se está com outra pessoa cuidando, ela não vai estar nem aí para aquilo ali, mas você percebe... [...] Você consegue respeitar a criança, as limitações dela, as particularidades dela, você é mãe e consegue corrigir coisas que você acha que são importantes na vida. A criança acha que pode fazer tudo, não pode fazer tudo, pode fazer tudo dentro do que é certo. Você colocar esses limites e deixar esses limites claros para a criança eu acho que é importante. Ter um contato maior com a mãe, você tem a possibilidade, a chance de desenvolver ele como ser humano amável, mais sociável, você entregar para a sociedade outro tipo de pessoa, e não o que está acontecendo hoje, com a infância, com as crianças. Mas tem desvantagens, porque a criança é mais confiante, mas ela acaba tendo uma dependência maior, porque a mãe está perto o tempo todo. A desvantagem é que você acaba privando ela de sofrimentos que ela teria se estivesse em outro contexto, tendo que se virar desde nova, várias situações em que ela não teria a mãe por perto. Você tem que escolher, nada é 100\% certo, tudo vai ter vantagem $\mathrm{e}$ desvantagem. Entregar o menino na escola com três meses vai ter coisa boa, muito boa para ele, mas ele vai perder muito com isso daí também. (ENTREVISTADA 13)

\section{Análise comparativa dos grupos entrevistados}

Ao confrontar as respostas obtidas junto ao grupo de mulheres sem formação superior que abdicaram da carreira para se dedicarem integralmente aos filhos com as respostas do grupo de mulheres com formação superior que fizeram o mesmo, nota-se que, independente do grau de escolaridade, a motivação para a maternidade residiu, basicamente, no desejo de ampliar a família e de vivenciar a experiência de ser mãe, assim como na segurança atribuída ao relacionamento em que se encontravam.

Todavia, no grupo de mulheres de menor escolaridade, provavelmente de menor renda, foi possível observar que a gravidez vem acompanhada, algumas vezes, de pressões diversas por parte das pessoas com quem elas convivem, o que as expõe a uma carga de tensão emocional logo no início da experiência da maternidade.

Além disso, verificou-se que, nos dois grupos, a maioria das mulheres somente decidiu interromper a carreira depois do nascimento do filho, ou seja, esta não é, muitas vezes, uma decisão tomada durante a gravidez. Todavia, é importante acrescentar que, entre as mães sem ensino superior que se dedicaram integralmente à maternidade, é também comum que durante a gestação elas já tenham se decidido pelo não retorno ao mercado de trabalho.

Entre os fatores que motivaram a decisão de interromper a carreira, destacaram-se, entre as mulheres com ensino superior, o desejo de darem maior atenção aos filhos e a dificuldade de conciliarem o trabalho e a maternidade, que dá origem a recorrentes conflitos entre essas duas dimensões da vida da mulher, os quais também foram levantados 
no estudo de Edwards (2006). Já entre as mulheres de menor escolaridade, além do desejo de estarem mais próximas dos filhos e da insegurança em deixá-los com terceiros, recebeu destaque a questão financeira associada à impossibilidade de deixar a criança com familiares, pois, caso se mantivessem no mercado, o salário seria apenas suficiente para arcar com os gastos com creche ou babá ou mesmo insuficiente para isso.

Tal resultado revela, em primeiro lugar, que muitas profissionais, após a maternidade, interrompem a carreira por alimentarem a crença de que seus filhos não seriam bem cuidados em pré-escolas, creches ou por babás, corroborando os apontamentos de Beltrame e Donelli (2012); e, em segundo lugar, que o Brasil ainda carece de um sistema de cuidados infantis amplamente acessível e de baixo custo, assim como existe na Noruega, onde, segundo Rønsen e Kitterød (2015), as trabalhadoras de menor renda têm condições de retornarem ao mercado laboral mais rapidamente depois do nascimento de seus filhos.

O preconceito, por sua vez, foi apontado pelas entrevistadas dos dois grupos como um fator que contribuiu para a interrupção da carreira, o que encontra respaldo nos estudos de Bruschini e Puppin (2004), que apontam para o desgaste emocional das mães inseridas no meio empresarial em decorrência da convivência com colegas, chefes e subordinados preconceituosos. De forma complementar, foi possível constatar que as organizações nas quais as entrevistadas trabalhavam possuíam poucas ou nenhuma política voltada para as funcionárias com filhos, evidenciando que as empresas ainda precisam aperfeiçoar diversos pontos para garantirem, de forma efetiva, condições favoráveis à permanência das mulheres no mercado de trabalho após a maternidade. Ou seja, verifica-se que ainda há muito a ser feito no âmbito organizacional para garantir que as trabalhadoras que têm filhos possam equilibrar a dimensão profissional e a maternal de suas vidas, o que vem ao encontro das conclusões de Goulart Júnior et al. (2013).

Como visto em Sina (2005), Edwards (2006), Leone e Baltar (2008) e Vieira e Amaral (2013), todas as mulheres afirmaram que enfrentavam uma dupla jornada de trabalho antes de abdicarem da carreira e, apesar de afirmarem que possuíam auxilio nas tarefas domésticas, sentiam-se sobrecarregadas, fator que também as motivou a se dedicarem integralmente à maternidade.

O assentimento do companheiro em relação à decisão de deixarem o mercado de trabalho foi apontado pela maioria das entrevistadas como um fator de estímulo, sendo escassos os casos descritos, entre os dois grupos de mulheres, de falta de suporte conjugal para interromperem a carreira e se dedicarem integralmente aos filhos.

Da mesma forma, o apoio dos familiares foi apontado pela maioria das mães como sendo de suma importância para que fosse levada adiante a decisão de abdicarem da carreira, sendo poucos também os casos em que houve desaprovação familiar.

Todavia, extrapolando o círculo conjugal e familiar, todas as participantes do estudo relataram conviver com inúmeras críticas e cobranças, mesmo que veladas, por não estarem no mercado de trabalho e, independente do nível de escolaridade, afirmaram sentir-se de alguma forma pressionadas a regressarem ao mercado, o que corrobora os apontamentos de Beltrame e Donelli (2012).

A maioria das entrevistadas dos dois grupos também relatou que, mesmo depois de interromper a carreira, recebe ajuda do companheiro nos cuidados com os filhos e a casa; contudo, nem todas consideravam justa a divisão dessas tarefas. Aqui, é importante salientar que, entre as entrevistadas que consideravam a divisão de tarefas domésticas pouco equitativa, predominava um discurso que denotava certo conformismo com a situação, o que indica que o machismo acaba sendo internalizado pelas próprias mulheres.

Tal constatação encontra respaldo no estudo de Amaral (2013), que indica que a sociedade, de modo geral, ainda hoje possui traços patriarcais e machistas, assimilando exclusivamente à identidade feminina as responsabilidades domésticas, como organização e limpeza do lar, e os cuidados com os filhos.

Quando indagadas se tomariam a mesma decisão depois de terem vivenciado essa experiência, a maioria das mães, independente do nível de escolaridade, respondeu positivamente, destacando o fato de terem conseguido superar as dificuldades/pressões que enfrentaram, assim como a maior participação no processo educacional dos filhos. Neste sentido, verifica-se que a taxa de arrependimento é pequena entre as mulheres entrevistadas que optaram por priorizar a maternidade em detrimento da carreira.

Tal resultado corrobora a constatação de Jung e Heppner (2015) de que as mães em tempo integral experimentam grande satisfação pessoal ao refletirem acerca do quão significativo e importante foi seu papel 
e atuação na formação e educação de seus filhos, apesar do ônus profissional que tiveram que assumir para isso.

Por outro lado, todas as mulheres entrevistadas pensam ou já pensaram em retornar ao mercado laboral, esbarrando em fatores como a dificuldade de ter alguém confiável com quem pudessem deixar o filho. Entre as mães com menor nível de instrução, havia ainda o receio de não se conseguir vaga em uma creche pública e a preocupação com o fato de que o salário recebido provavelmente não seria suficiente para arcar com os custos de uma creche ou babá.

Aqui, novamente se percebe a importância de aprimorar a rede de cuidados infantis, de modo a torná-la mais acessível e menos onerosa para as mães de menor rendimento, o que já ocorre em outros países mais desenvolvidos (RØNSEN; KITTERØD, 2015), considerando que, em muitos casos, o tempo de interrupção da carreira tende a ser inversamente proporcional à renda obtida pela mulher antes do nascimento do filho e afastamento do mercado de trabalho (BÄCHMANN; GATERMANN, 2017).

Mas, mesmo diante de todos esses fatores, a maior parte das entrevistadas planeja retornar ao mercado de trabalho quando os filhos estiverem mais velhos e menos dependentes. Há, contudo, uma inquietação compartilhada por todas elas quanto à dificuldade que enfrentarão para regressarem. Neste ponto da discussão, faz-se importante acrescentar que tal preocupação não é infundada, à medida que o mercado normalmente penaliza a maternidade em tempo integral ao invés de facilitar o reingresso das profissionais que temporariamente interromperam sua carreira visando proporcionar maiores cuidados a seus filhos no período em que os mesmos são mais dependentes (ARUN; ARUN; BOROOAH, 2004; BÄCHMANN; GATERMANN, 2017).

No caso específico das mulheres com ensino superior, essa inquietação relaciona-se à dificuldade de voltarem a atuar em sua área de formação, o que acaba levandoas a retomarem os estudos ou mesmo a pensarem em abrir um negócio próprio no futuro. Tal constatação encontra respaldo no estudo de Lovejoy e Stone (2012), que aponta para o fato de muitas mães, ao decidirem retornar ao mercado de trabalho depois de um tempo mais ou menos longo de afastamento, buscarem profissões alternativas para contornarem a desatualização profissional, a falta de flexibilidade de seus antigos empregos e a provável discriminação etária que terão que enfrentar.
Como benefícios advindos da decisão de interromperem a carreira para se dedicarem integralmente à maternidade, as mães dos dois grupos elencaram o fato de poderem acompanhar mais de perto o desenvolvimento de seus filhos e atuarem mais ativamente em sua educação.

Como desvantagens, as mulheres com formação superior citaram a estagnação da carreira, a maior dependência que a criança acaba desenvolvendo e o sentimento de inferioridade por estarem fora do mercado de trabalho formal. Já as mulheres sem formação superior mencionaram a maior restrição financeira experimentada no dia a dia, assim como a sensação de não serem úteis na sociedade. Nos dois casos, ficam evidentes os conflitos psicológicos e as angústias com as quais as mulheres que decidem abdicar da carreira precisam lidar nesse processo, independentemente de seu nível de instrução.

\section{Considerações finais}

A sociedade contemporânea configura-se a partir de inúmeras contradições, seja no âmbito político, no econômico, no social, etc., que perpassam também pelas questões de gênero. Ao mesmo tempo em que as mulheres passaram a ter mais abertura no mercado de trabalho, muitas também se depararam com dificuldades diversas para se manterem nele depois de assumirem o papel de mães.

Ou seja, apesar de avanços consideráveis, ainda há um caminho longo a ser trilhado para que as mulheres tenham efetivamente as mesmas condições e recebam um tratamento equânime em relação àquele dispensado aos homens. Se antes o desafio era ingressar no mercado laboral, atualmente as mulheres têm que superar barreiras diversas para ascenderem profissionalmente e também para darem continuidade a suas carreiras depois da maternidade.

Neste contexto, é comum que as mulheres tenham que lidar com o dilema existente entre a carreira e a maternidade. Abdicar do trabalho remunerado e se dedicar integralmente à maternidade ou conciliar ambos é uma decisão difícil, que traz consequências duradouras e significativas para a vida da mulher.

Tal temática, apesar de relevante e atual, ainda não recebeu a devida atenção no meio acadêmico, tendo sido pouco explorada até o momento. Todavia, devese reconhecer que as condições correntes mostram-se 
propícias para que discussões como essa sejam levadas adiante e permitam uma reflexão mais ponderada por parte da sociedade.

Neste sentido, estabeleceu-se como objetivo para esta pesquisa analisar a motivação das mulheres que decidiram abdicar da carreira para se dedicarem integralmente à maternidade, assim como a percepção delas a respeito da experiência que vivenciaram a partir dessa decisão e suas perspectivas futuras.

Após conduzir entrevistas em profundidade com 14 mães, constatou-se que a decisão de interromper a carreira se dá normalmente após o nascimento do filho, sendo esta resolução motivada, no caso das mulheres com ensino superior, pela dificuldade de conciliar o trabalho e a maternidade, assim como pelo desejo de dar maior atenção aos filhos. No caso das mulheres com menor escolaridade e, provavelmente, menor renda, a decisão se dá pelo desejo de acompanhar de forma mais próxima os filhos, pela impossibilidade (ou pouca viabilidade) de arcar com os custos de uma creche ou babá e também pela insegurança de deixar a criança com terceiros.

De forma complementar, a dupla jornada de trabalho enfrentada pelas mulheres que retornaram ao mercado $\operatorname{logo}$ depois que terminou a licença-maternidade também foi um fator que as motivou a abdicarem da carreira e se dedicarem integralmente à maternidade, assim como o assentimento e apoio do companheiro e dos familiares.

Entre os resultados obtidos, nota-se o preconceito sofrido pelas mães no âmbito organizacional, independente de seu nível de escolaridade, assim como a ausência ou escassez de políticas de gestão voltadas para as funcionárias que possuem filhos, o que indica algumas lacunas a serem preenchidas pelas organizações para favorecerem a permanência das mulheres no mercado após a maternidade.

Depois de deixarem o mercado, as entrevistadas relataram que passaram a conviver com críticas e cobranças por não estarem mais trabalhando fora de casa, o que gera um desgaste emocional extra. E, apesar de receberem ajuda do companheiro nos cuidados com os filhos e a casa, muitas não consideram justa a divisão atual das tarefas.

A despeito disso, a taxa de arrependimento por terem interrompido a carreira é pequena entre as entrevistadas. Por outro lado, todas pensam ou já pensaram em retornar ao mercado de trabalho, sendo uma inquietação das mesmas as dificuldades que enfrentarão futuramente para isso. Ou seja, independente do nível de instrução, ficaram evidentes os conflitos psicológicos e as angústias provenientes do dilema entre a carreira e a maternidade.

Em relação às diferenças observadas nas respostas das entrevistadas de acordo com seu nível de instrução, percebeu-se que, enquanto no grupo sem formação superior somente duas das mães percebiam distinções no tratamento dispensado a homens e mulheres no local onde trabalhavam, no grupo com formação superior somente duas não percebiam tais distinções; as outras cinco relataram diferenças salariais, de oportunidades, além de paradigmas preconceituosos arraigados na cultura da organização. Tal resultado indica que o tratamento despendido aos profissionais tende a ser mais desigual entre os gêneros nos níveis organizacionais menos operacionais.

Outro aspecto que merece destaque é que, mesmo tendo todas as entrevistadas afirmado que enfrentam grande cobrança para regresso ao mercado de trabalho, ficou evidente que, no grupo das mulheres que têm graduação, essa cobrança acentua-se devido ao fato de terem estudado mais; além disso, elas mesmas acabam internalizando essa pressão e passam também a se cobrar pelo retorno.

No que se refere ao reingresso no mercado de trabalho, nota-se que, no grupo das mães sem graduação, a preocupação maior gira em torno da questão financeira. Elas têm aflições associadas ao fato de não conseguirem vaga em creches públicas e também não conseguirem contratar uma babá devido aos baixos salários que receberiam. Por outro lado, a preocupação das mulheres graduadas está ligada à experiência reduzida em sua área de atuação e à concorrência das mulheres que não interromperam a carreira, que levam vantagem nos processos de seleção.

Neste sentido, deve-se considerar que os resultados obtidos levam ao questionamento das políticas e práticas organizacionais e das políticas públicas vigentes que são voltadas para as profissionais que possuem filhos. Práticas como bome-office, telework, flexibilização do horário e redução da jornada, assim como o enfrentamento dos preconceitos arraigados na cultura das organizações, apesar de extremamente importantes para garantirem condições às mulheres que têm filhos de permanecerem no mercado de trabalho, ainda não são amplamente adotadas no meio empresarial. Da mesma forma, é possível auferir 
que as políticas públicas de expansão do número de vagas em creches públicas não têm sido tão efetivas, à medida que ainda não são capazes de atender às demandas sociais latentes.

Os resultados alcançados articulam-se com as discussões encontradas na literatura nacional e internacional sobre o tema abordado, pois perpassa por elementos como a identidade feminina e sua associação, sob a ótica sociocultural ainda vigente, com o papel de mãe sobrepujando o profissional; a sobrecarga feminina que decorre da divisão pouco equitativa das responsabilidades domésticas e familiares entre os gêneros; os conflitos relacionados à conciliação ou não da maternidade e a carreira (seja optando por conciliar essas duas dimensões de sua vida ou por não fazê-lo, a mulher é julgada e pressionada pelos outros e também por si mesma); a penalização, no mercado de trabalho, da profissional que interrompe a carreira para se dedicar integralmente ao filho; a necessidade de arranjos laborais flexibilizados nas organizações e de políticas públicas mais efetivas quanto à rede de cuidados infantis; e a elevada satisfação pessoal experimentada em virtude da maternidade integral.

Com isso, aponta-se que a principal contribuição desta pesquisa é tratar a interrupção voluntária da carreira em prol da maternidade em tempo integral de forma holística, coadunando diversos aspectos teóricoempíricos, normalmente discutidos separadamente na literatura.

Para finalizar, espera-se que esta pesquisa estimule uma reflexão, para que, no futuro, seja possível mitigar problemas de ordem social e cultural envolvendo os preconceitos e pressões sofridas pelas mulheres nas organizações e no âmbito familiar ao se tornarem mães, estimulando também reflexões acerca do papel social que as empresas deveriam desempenhar para favorecer a conciliação entre a maternidade e a carreira.

Para estudos futuros, sugere-se ampliar a amostra e adotar uma abordagem quantitativa para comprovar os resultados aqui alcançados. Adicionalmente, sugere-se que novas pesquisas sejam efetuadas com o intuito de levantar as práticas e políticas adotadas pelas organizações que estão engajadas em prover às profissionais que possuem filhos condições que favoreçam sua permanência ou reingresso no mercado de trabalho.

\section{Referências}

AMARAL, G. A. Os desafios da inserção da mulher no mercado de trabalho. Itinerarius Reflectionis, v. 8, n. 2, p. 1-20, 2013.

ARUN, S. V.; ARUN, T. G.; BOROOAH, V. K. The effect of career breaks on the working lives of women. Feminist Economics, v. 10, n. 1, p. 65-84, 2004.

BÄCHMANN, A.-C.; GATERMANN, D. The duration of family-related employment interruptions: the role of occupational characteristics. Journal for Labour Market Research, v. 50, n. 1, p. 143-160, 2017.

BARBOSA, P. Z.; COUTINHO, M. L. R.

Maternidade: novas possibilidades, antigas visões.

Psicologia Clínica, v. 19, n. 1, p. 163-185, 2007.

BAYLÃO, A. L. S.; SCHETTTINO, E. M. O.

A inserção da mulher no mercado de trabalho

brasileiro. In: XI Simpósio de Excelência em Gestão e Tecnologia. 2014, Londrina. Anais do XI SEGeT, 2014.

BELTRAME, G. R.; DONELLI, T. M. S. Maternidade e carreira: desafios frente à conciliação de papéis. Aletheia, n. 38-39, p. 206-217, 2012.

BONI, V.; QUARESMA, S. J. Aprendendo a entrevistar: como fazer entrevistas em ciências sociais. Em Tese, v. 2, n. 1, p. 68-80, 2005.

BRUSCHINI, C.; PUPPIN, A. B. Trabalho de mulheres executivas no Brasil no final do século XX. Caderno de Pesquisa, v. 34, n. 121, p. 105138, 2004.

CAPPELLE, M. C. A.; MELO, M. C. O. L.; SOUZA, N. L. Mulheres, trabalho e Administração. Revista

Interdisciplinar de Gestão Social, v. 2, n. 2, p. 161191, 2013.

\section{CARMO, H.; FERREIRA, M. Metodologia da} investigação: guia para autoaprendizagem. 2. ed. Lisboa: Universidade Aberta, 2008.

CARVALHO NETO, A. M.; TANURE, B.; ANDRADE, J. Executivas: Carreira, Maternidade, Amores e Preconceitos. RAE - Eletrônica, v. 9, n. 1, p.1-23, 2010.

CASSIANI, S. H. B.; CALIRI, M. H. L.; PELA, N. T. R. A teoria fundada nos dados como abordagem da 
pesquisa interpretativa. Revista Latino-Americana de Enfermagem, v. 4, n. 3, p. 75-88, 1996.

CASTRO, I. Mamãe vai trabalhar e volta já. São Paulo: Original, 2006.

CEBRIÁN, I.; MORENO, G. The effects of gender differences in career interruptions on the gender wage gap in Spain. Feminist Economics, v. 21, n. 4, p. 1-27, 2015.

CERIBELI, H. B.; FERREIRA, F. J. R. Análisis de la relación entre flexibilidad del trabajo, compromiso organizacional y intención de permanecer en la organización. Revista de Globalización, Competitividad y Gobernabilidad de Georgetown, v. 10, n. 3, p. 37-56, 2016.

EDWARDS, M. The role of husbands' supportive communication practices in the lives of employed mothers. Marriage \& Family Review, v. 40, n. 4, p. 23-46, 2006.

EVERTSSON, M.; GRUNOW, D.; AISENBREY, S. Work interruptions and young women's career prospects in Germany, Sweden and the US. Work, Employment and Society, v. 30, n. 2, p. 291-308, 2016.

FONSECA JUNIOR.; WILSON, C. Análise de conteúdo. In: DUARTE, J.; BARROS, A. (Orgs.). Métodos e técnicas de pesquisa em comunicação. São Paulo: Atlas, 2005.

GOULART JÚNIOR, E.; FEIJÓ, M. R.; CUNHA, E. V.; CORRÊA, B. J.; GOUVEIA, P. A. E. S. Exigências familiares e do trabalho: um equilíbrio necessário para a saúde de trabalhadores $\mathrm{e}$ organizações. Pensando Famílias, v. 17, n. 1, p. 110-122, 2013.

IBGE. Estatística de gênero: uma análise dos resultados do censo demográfico 2010. Estudos e Pesquisas. Informação Demográfica e Socioeconômica número 33. Rio de Janeiro, 2014.

IBGE. Principais destaques da evolução do mercado de trabalho nas regiões metropolitanas abrangidas pela pesquisa: Retrospectiva da Pesquisa Mensal de Emprego - PME 2003-2016.

JUNG, A.-K.; HEPPNER, M. J. Work of full-time mothers: putting voice to the relational theory of working. Career Development Quarterly, v. 63, n. 3, p. 253-267, 2015.
LEONE, E. T.; BALTAR, P. A mulher na recuperação recente do mercado de trabalho brasileiro. Revista Brasileira de Estudos da População, v. 25, n. 2, p. 233-249, 2008.

LIMA, M. G. R. Um estudo sobre o adiamento da maternidade em mulheres contemporâneas. 2012. 202 f. Tese (Doutorado em Psicologia Clínica) - Instituto de Psicologia, Universidade de São Paulo, São Paulo, 2012.

LOVEJOY, M.; STONE, P. Opting back in: the influence of time at home on professional women's career redirection after opting out. Gender, Work and Organization, v. 19, n. 6, p. 631-653, 2012.

MAGALHÃES, B; SILVA. G. A mulher no trabalho, na família e na universidade. Revista Eletrônica Arma da Crítica, v. 2, n. 2, p.177-193. 2010.

McINTOSH, B.; McQUAID, R.; MUNRO, A.; DABIR-ALAI, P. Motherhood and its impact on career progression. Gender in Management, v. 27, n. 5, p. 342-360, 2012.

MONTEIRO, R. C. Pesquisa qualitativa como opção metodológica. Pro-Posições, v. 2, n. 2, p. 27-35, 2016.

OLIVEIRA, S. C.; FARIA,E. R.; SARRIERA, J. C.; PICCININI, C. A.; TRENTINI, C.M.

Maternidade e trabalho: uma revisão da literatura.

Interamerican Journal of Psychology, v. 45, n. 2, p. 271-280, 2011.

PACELLI, L.; PASQUA, S.; VILLOSIO, C. Labor market penalties for mothers in Italy. Journal of Labor Research, v. 34, n. 4, p. 408-432, 2013.

PATIAS, N. D.; BUAES, C. S. "Tem que ser uma escolha da mulher" representações de maternidade em mulheres não-mães por opção. Psicologia \& Sociedade, v. 24, n. 2, p. 300-306, 2012.

QUIVY, R.; CAMPENHOUDT, L. V. Manual de investigação em Ciências Sociais. Lisboa: Gradiva, 1998.

RAPOPORT, A.; PICCININI, C. A . Uma escolha do cuidado alternativo para o bebê e criança pequena. Estudos de Psicologia, v. 9, n. 3, p. $497-$ 503, 2004.

RAUPP, F. M.; BEUREN, I. M. Metodologia da pesquisa aplicável às Ciências Sociais. Como 
elaborar trabalhos monográficos em

contabilidade: teoria e prática. São Paulo: Atlas, 2003. p. 76-97.

RIBEIRO, W. V.; COSTA, R. R.; SILVA, C. M. M.; LOPES, V. M. Oocyte reception: patients' profile in a waiting list of the program of Hospital Regional da Asa Sul, Brasília, Distrito Federal. Revista

Brasileira de Ginecologia e Obstetrícia, v. 29, n. 9, p. 459-464, 2007.

RØNSEN, M.; KITTERØD, R. H. Genderequalizing family policies and mothers' entry into paid work: recent evidence from Norway. Feminist Economics, v. 21, n. 1, p. 59-89, 2015.

SIMOES, F. I. W.; HASHIMOTO, F. Mulher, mercado de trabalho e as configurações do século XX. Revista Vozes dos Vales, v. 1, n. 2, p. 1-25, 2012.

SINA, A. Mulher e trabalho: o desafio de conciliar diferentes papéis na sociedade. São Paulo: Saraiva, 2005.

TANURE, B.; CARVALHO NETO, A.; ANDRADE, J. O. A super executiva às voltas com carreira, relógio biológico, maternidade, amores e preconceitos. In: XXX Encontro Nacional de Programa de Pós-Graduação em Administração, Salvador, 2006. Anais XXX EnANPAD, 2006.

THEUNISSEN, G.; VERBRUGGEN, M.; FORRIER, A.; SELS, L. Career sidestep, wage setback? The impact of different types of employment interruptions on wages. Gender, Work and Organization, v. 18, n. 1, p. 110-131, 2011.

TOMAZ, R. Feminismo, maternidade e mídia: relações historicamente estreitas em revisão. Galáxia, n. 29, p. 155-166, 2015.

VIEIRA, A.; AMARAL, G. A. A arte de ser BeijaFlor na tripla jornada de trabalho da mulher. Saúde e Sociedade, v. 22, n. 2, p. 403-414, 2013. 